\title{
Estudo psicossocial de um seminário teológico: a formação do clero católico em análise ${ }^{1}$
}

\author{
Silvio José Benelli \\ Universidade Estadual Paulista - Assis
}

\begin{abstract}
Resumo
Este artigo apresenta dados preliminares e discussões de uma investigação em psicologia social sobre a produção da subjetividade eclesiástica. Utilizando o instrumental teórico da análise institucional, estudamos o dispositivo pedagógico seminário. Nosso campo de pesquisa é um seminário católico de teologia, onde vivem 50 seminaristas em regime de internato, na etapa final de preparação para o sacerdócio, os quais, uma vez ordenados, passarão a ocupar posições de relevância que consistem na coordenação de comunidades paroquiais amplas. Os dados foram obtidos por meio da observação do cotidiano institucional. Apresentamos algumas conclusões preliminares. Encontramos fortes contradições entre os discursos oficiais e as práticas cotidianas no seminário teológico.
\end{abstract}

Palavras-chave: psicologia e religião; análise institucional; produção de subjetividade; seminário católico; formação eclesiástica

\begin{abstract}
Social psychology study at a theological seminary: ecclesiastical catholic formation in analysis. This article introduces preliminary data and debates from a social psychology inquiry about the production of ecclesiastical subjectivity. By taken institutional analysis as a theoretical tool, we study the seminary as a pedagogical device. Our field research is at a catholic theological seminary, where 50 seminarians live in boarding system, at the final stage of preparation to the priesthood; once ordained, the new priests will be in relevant position to coordinate extended parish communities. Data were obtained by means of observation of the institutional daily life. Some preliminary conclusions are presented. We have found deep contradictions between official discourses and daily practices at the theological seminary.
\end{abstract}

Keywords: psychology and religion; institutional analysis; production of subjectivity; catholic seminary; ecclesiastical formation

\section{Análise institucional de um seminário teológico}

Esta pesquisa em Psicologia Social visa problematizar as práticas formativas eclesiásticas católicas, tais como elas se apresentam nos modos de funcionamento institucional do seminário católico e no registro do saber eclesiástico, como produtoras de uma possível subjetividade eclesiástica (futuros padres). Nossa perspectiva analítica é baseada em operadores da análise institucional, pois uma abordagem psicológica nos moldes tradicionais da área não nos pareceu suficientemente adequada para a compreensão de tal problemática. Para estudarmos a multifacetada realidade que é a formação sacerdotal e a instituição seminário católico onde ela se processa, necessitamos de uma abordagem também complexa. Buscamos ferramentas teórico-técnicas em diversos autores: na microssociologia de Goffman (1987); na análise institucional de Lourau (1996); na abrangente perspectiva esquizoanalítica de Baremblitt (1998); na genealogia de Foucault (1999), na grade analítica de base lógico-histórica e de inspiração marxista dialética, criada por
Costa-Rosa (2000, 2006); na psicologia social clínica de BarusMichel (2004); na análise genealógica de 0Ferreira Neto (2004). Neles encontramos operadores que nos permitiram realizar uma pesquisa transversal, transitando por diferentes campos de saberes e práticas sociais: história da Igreja, teologia católica, psicologia social, pensamento institucionalista e também foucaultiano, buscando cartografar nosso objeto: a produção de subjetividade num seminário teológico católico.

O movimento institucionalista inclui um conjunto de escolas, tendências ou linhas de pensamento complexos, com elementos comuns e outros bastantes específicos (Baremblitt, 1998). Não nos alinhamos particularmente a nenhuma escola ou corrente de análise institucional, mas lançamos mão de instrumentos teóricos de alguns pensadores que nos pareceram pertinentes e eficazes para a realização de nossas análises. Entendemos que para estudar como estão sendo formados os seminaristas católicos que futuramente serão padres, seria útil uma abordagem institucional através da qual pudéssemos problematizar as práticas formativas (práticas discursivas, práticas de poder e tecnologias de si) que 
são implementadas num seminário teológico, tomando essa instituição como dispositivo de produção de subjetividade. Tecemos, assim, uma grade de análise composta pela análise institucional na perspectiva da produção de subjetividade.

Foucault (1999) produziu uma análise histórica do desenvolvimento das práticas punitivas e disciplinares que nos parece muito adequada para analisarmos a atual formação institucional do clero católico. De uma perspectiva psicossocial, a formação social seminário católico parece se organizar a partir dos operadores apresentados por Foucault. Eles seriam parte do não-dito e do não-sabido das funções institucionais tradicionais. Como equipamento, o seminário teológico emprega práticas discursivas, práticas não-discursivas e implementa práticas de si que têm como efeito a produção institucional de sujeitos, de atores sociais, de padres católicos. Buscamos estudar o plano dos saberes teológicos e espirituais, a dimensão das práticas psicopedagógicas cotidianas através da observação participante, visando captar os diversos processos através dos quais se produz subjetividade no seminário teológico católico.

De modo complementar, a leitura de Goffman (1987), a partir das análises de Foucault (1999), pode nos proporcionar um enriquecimento fecundo na compreensão dos processos de produção de subjetividade na sociedade contemporânea e, de modo específico, no contexto das instituições totais, que estão longe de terem desaparecido (Benelli, 2004). Consideramos que Goffman (1987) realiza uma modalidade de análise institucional que pode ser situada como transitando entre os planos macro (ou molar) e micro dos fenômenos que ocorrem nos estabelecimentos fechados. Goffman (1987) analisa as práticas não-discursivas, ele as articula com grande sutileza, fazendo os detalhes mais pitorescos e aparentemente insignificantes do cotidiano institucional falarem; percebemos então o plano microfísico das relações intra-institucionais, mergulhando nas diferentes estratégias nas quais o poder se ramifica, circula, domina e produz saberes e sujeitos. Esse instrumental teórico constitui o pano de fundo de nossas análises da formação sacerdotal institucional.

\section{Literatura católica sobre a formação do clero}

Os fundamentos teológicos da formação se encontram na Bíblia e na doutrina da Igreja consignada em seus documentos: textos do Concílio Vaticano II (Igreja Católica, 1982), dos últimos Papas, das conferências episcopais latino-americanas e brasileira. As disposições oficiais para a formação sacerdotal estão contidas no Código de Direito Canônico (Igreja Católica, 1983), na Ratio Fundamentalis Institutionis Sacerdotalis (Igreja Católica, 1985) e na Exortação papal Pastores Dabo Vobis, de João Paulo II (1992) que foram adaptadas e aplicadas às condições da Igreja do Brasil. Esse conjunto de documentos forma o plano discursivo oficial da Igreja católica quanto ao processo formativo sacerdotal, contendo as orientações teológicas relativas ao presbiterato e seus desdobramentos pedagógicos, psicológicos e espirituais, que devem ser implementados nos estabelecimentos dedicados à formação do clero. As novas orientações eclesiásticas romanas reformuladas na década de 1990 (João Paulo II, 1992) foram aplicadas em seguida no Brasil (Conferência Nacional dos Bispos do Brasil, 1995), adaptando as diretrizes pontifícias para a realidade nacional. Foi nesse contexto que os bispos da província eclesiástica decidiram fundar e criar o seminário que investigamos, de acordo com as novas orientações romanas. Houve um retorno para o modelo do seminário clássico tradicional, fórmula de evidente sucesso no passado. Mas os tempos mudaram e a sociedade se transformou. Velhos problemas retornaram no plano disciplinar e na dimensão da espiritualidade também houve um retraimento em direção ao culto, ao sacramento, um retorno ao mundo religioso e sagrado por excelência (Benelli, 2006b).

Na literatura tradicional dedicada ao tema dos saberes teológicos e pedagógicos relativos ao processo formativo (Centini, 1997; Centini \& Manenti, 1988; João Paulo II, 1992; Maciel, 1992; Conferência Nacional dos Bispos do Brasil, 1995, 2001; Moro, 1997; Mézerville, 2000; Cozzens, 2001; Nouwen, 2001; Marmilicz, 2003; Organização dos Seminários e Institutos do Brasil, 2004; Agência de Notícias Zenit, 2006), o enfoque que estamos procurando desenvolver, uma abordagem institucional da problemática da formação do clero diocesano é rara, embora já haja alguns trabalhos entre as congregações religiosas (Losada, Lapenta, Sá, \& Almeida, 1999, Pereira, 2004, 2005). Essa literatura especificamente católica, ao ser elaborada no plano teológico e pastoral, tende a ignorar o próprio campo eclesial global que é tomado como pano de fundo tacitamente homogêneo, não-problemático e nem contraditório (Libanio, 1984, 2000, 2005; Beozzo, 1993; Boff, 1996). Mas entendemos que ele é capaz de afetar o modo de funcionamento do seminário com grande eficácia (Benelli, 2006b): postulamos que para entender o seminário atual é preciso também estudar os paradigmas em conflito no contexto eclesial mais amplo.

\section{Observação participante no contexto institucional de um seminário católico teológico}

$\mathrm{O}$ universo pesquisado inclui um estabelecimento denominado seminário teológico católico localizado no interior do Estado de São Paulo e seus diversos atores institucionais: seminaristas estudantes de teologia, cujas idades variam entre 22 e 40 anos, padres formadores: reitor, diretor de estudos, diretor espiritual, cujas idades variam entre 48 e 65 anos, além de professores, técnicos administrativos e demais funcionários. O número de seminaristas em formação varia conforme o ano, mas normalmente há entre 40 e 60 formandos no seminário.

Para realizar essa pesquisa, utilizamos a técnica da observação participante, qualitativa, rigorosa, sistemática e vivencial (Richardson, 1985; Alves-Mazzotti \& Gewndsznajder, 1998; Benelli, 2006a). A participação não implicou um delineamento conjunto, pois não havia demanda de análise por parte da instituição seminário, embora houvesse bastante sofrimento ali. A técnica da observação participante foi utilizada e reorientada para manter-se adequada e sensível às características da situação. Entendemos a pesquisa como prática investigativa e a participação como valorização e uso das perspectivas vivenciadas pelos sujeitos na vida e ambientes cotidianos. A observação participante foi não-estruturada, isto é, nela os fenômenos a serem observados não eram predeterminados, eles foram observados e relatados da forma como aconteceram, visando descrever e compreender o que estava ocorrendo na 
situação dada.

Na elaboração dos relatos de observação do campo utilizamos diversos documentos e fontes de informação, tais como: diálogos informais, planos pedagógicos, relatórios institucionais, atas de reuniões e assembléias, planos de curso, dados estatísticos, perfil dos alunos e dos professores, cartazes, avisos, circulares, formulários, folhetos de circulação interna e normas. Produzimos um longo e minucioso relatório do qual apresentaremos aqui apenas alguns aspectos mais relevantes.

\section{Relatos das observações de campo}

Tendo começado com nossas visitas de observação participante ainda em 2003, estivemos presentes semanalmente no seminário teológico. Às vezes, passávamos o dia inteiro, toda uma tarde ou uma parte da noite no local. De 2004 até o primeiro semestre de 2006, prosseguimos acompanhando a vida dos estudantes de teologia e dos padres formadores no contexto institucional: missas, aulas, refeições, momentos de espiritualidade, jornadas de estudos, festas, comemorações do aniversário do instituto teológico, assembléias, sessões de recados, reuniões de formadores, convivências, tardes de trabalho doméstico, jogos olímpicos, reuniões formais e informais de seminaristas, formaturas, despedida e recepção de novos formadores, etc. Tivemos ocasião de acompanhar o cotidiano e também momentos especiais do seminário, verificando o funcionamento de diversos dispositivos político-pedagógicos em operação na instituição.

O seminário teológico é constituído por uma grande propriedade e diversos edifícios, que abrigam salas de aula, dormitórios, refeitório, capela, igreja, biblioteca, ambientes e espaços de convivência, tais como pátios e jardins. Ali se realiza a preparação teológica dos candidatos ao sacerdócio, que cursam o bacharelado em teologia, com quatro anos de duração. Além das atividades acadêmicas, outras dimensões específicas do processo formativo sacerdotal são implementadas no estabelecimento: vida comunitária, formação humano-afetiva, dimensão vocacional e espiritual e, ainda, atividades pastorais.

As alas do seminário teológico destinadas aos quartos dos seminaristas são intituladas poeticamente com nomes de santos: ala S. Luís Gonzaga, ala D. Hélder, ala Frei Galvão, ala S. José, ala S. Francisco, ala Madre Tereza. Há alas mais simples e rústicas, nas quais os quartos são menores e as paredes são feitas com divisórias de madeira. Há outras alas com aposentos mais espaçosos e feitos de alvenaria. Os seminaristas novatos ocupam as alas mais simples (ala S. Luís Gonzaga e ala S. José), os veteranos vivem nas melhores alas. À medida que os seminaristas vão se formando e retornando para suas dioceses, os novatos passam a ocupar os quartos melhores.

O seminário teológico funciona em regime de internato e embora a maioria dos estudantes internos já tenha obtido alguma titulação universitária, normalmente a licenciatura em Filosofia, o trabalho profissional é vedado aos seminaristas. As dioceses mantenedoras da instituição cobrem as despesas de pensão e estudos. O dinheiro continua sendo uma questão problemática para os formandos, que precisam suprir suas necessidades pessoais de algum modo. Apesar de possuírem capacitação profissional, permanecem sob a tutela eclesiástica. Só alcançarão a maioridade depois da ordenação sacerdotal.

De um modo geral, podemos afirmar que o funcionamento cotidiano do seminário teológico não difere muito do seminário filosófico ou de um seminário Menor². Um dia típico no seminário teológico começa com o levantar às 06:00h da manhã, às 06:30h é celebrada a missa da comunidade do seminário, que costuma durar aproximadamente 45 minutos; em seguida, há o café da manhã. As aulas começam às 08:10h, com intervalo de meia hora entre 10:00h e 10:30h. O almoço acontece às 12:00h. A tarde é livre, e entre 13:30h e 17:00h os seminaristas podem aproveitar o tempo para os estudos e trabalhos acadêmicos. A missa acontece às 17:00h e, em seguida, vem o jantar. A noite é livre e deve ser dedicada aos estudos.

Durante o tempo em que estivemos realizando essas visitas de observação tivemos a ocasião de presenciar o trabalho de três reitores e de dois diretores espirituais diferentes. Apenas o padre diretor de estudos permaneceu o mesmo o tempo todo. As relações dos seminaristas com a equipe de padres formadores continuam sendo formais e distantes, como verificado no seminário filosófico (Benelli, 2006a). Manter distância dos formadores dá segurança, pois evita o risco de que eles vejam erros ou defeitos passíveis de reprimenda ou correção. Os formadores convivem constantemente com os seminaristas: como professores na sala de aula, nas refeições, nos momentos de oração, como presidentes das celebrações eucarísticas. Os padres normalmente procuram ser simpáticos, próximos e dialogantes com os formandos.

Inevitavelmente, as relações de poder continuam agonísticas em surdina e, de vez em quando, as forças se crispam abertamente em enfrentamentos da autoridade pelos seminaristas, sobretudo no cenário pedagógico e acadêmico, espaço objetivo de grandes embates. A equipe de formadores continua soberana no seminário teológico, dotada de amplos poderes e de arbítrio, encarregada de observar, supervisionar e selecionar os candidatos considerados aptos para receber a ordenação sacerdotal. Os relatórios semestrais emitidos pelo reitor continuam operantes, embora não pareçam tão intimidadores quanto no seminário filosófico (Benelli, 2006a).

As assembléias comunitárias realizadas no seminário teológico são um dispositivo importante no funcionamento institucional. Para sua preparação, os grupos de seminaristas se reúnem por dioceses e elaboram uma lista de pontos positivos, negativos e sugestões quanto às dimensões comunitária, espiritual, acadêmica e litúrgica da vida no seminário teológico. Os formandos usualmente não apreciam as assembléias, que estão longe do que o nome parece indicar. Não se trata de modo algum da reunião de um grupo de sujeitos dotados de igualdade de direitos com poder soberano para avaliar, decidir e implementar uma vida e organização institucional baseada em seus próprios critérios. Apesar da denominação de assembléia, esse evento pode ser considerado uma concessão estratégica aos ares democráticos da atualidade, dentro do assim vagamente chamado método participativo, proposto pela Conferência Nacional dos Bispos do Brasil (1995, p. 54). Trata-se de um elemento da Pedagogia Nova (Cotrim, 1993; Libaneo, 1994; Benelli, 2006b) aplicado à formação sacerdotal, uma forma 
de participação controlada. Os teólogos se aborrecem nessas assembléias; apáticos, desejam que elas sejam o mais breves possível, pois reclamam que não resolvem nada de importante e tomam toda uma tarde, gastando muito tempo inutilmente. Desejam até mesmo que elas acabem ou que aconteçam o menor número de vezes possível.

Desde logo, não se trata de um evento realmente democrático e efetivamente participativo, já que os seminaristas sabem muito bem dentro de quais parâmetros devem permanecer: é preciso não tocar em temas fundamentais e nevrálgicos, há temas tabu que são cuidadosamente evitados, para não provocar a equipe de formadores e assim evitar sua ira e possíveis represálias. Temas tais como as relações de poder entre padres formadores e seminaristas, celibato, formas de organização políticopedagógicas da instituição seminário estão tacitamente proscritos da pauta e seria considerado inadequado aludir a eles. "Na Igreja, quem tem cabeça obedece, quem tem mitra, manda”, comentam os sábios estudantes de teologia. Na verdade, parece que os padres formadores tratam os seminaristas teólogos tal como o clero usualmente trata os leigos na vida eclesial: seminaristas/ leigos devem obedecer à hierarquia eclesiástica. Aí se explicita a contraposição eclesial clero X laicato, acentuando o poder e a superioridade dos padres com relação aos leigos. Através dos relatos das assembléias da comunidade é possível ter uma idéia da dinâmica institucional ao longo do ano. Elas são interessantes analisadores tanto pelo que se ventila nelas quanto pelas suas lacunas. O analisador institucional é uma ferramenta de pesquisa, ele não precisa ser constituído de material verbal, pode ser um monumento, uma planta arquitetônica, um arquivo, uma distribuição do tempo ou espaço na organização. Sua materialidade expressiva é totalmente heterogênea, sempre é analítico em si mesmo, contendo elementos para se autoentender, para começar o processo de seu próprio esclarecimento (Baremblitt, 1998).

Observamos que havia um conflito permanente e nem sempre silencioso entre a dimensão acadêmica e os outros aspectos da formação sacerdotal. Como se pode observar no projeto acadêmico oficial do curso teológico, a intenção seria formar padres comprometidos com o processo de libertação. Até mesmo utiliza-se uma bibliografia que ainda é marcada por diversos autores da Teologia da Libertação, conforme o programa das várias disciplinas. Curiosamente, os documentos do Concílio Vaticano II são estudados em diversas disciplinas, trata-se de um texto muito lido e bastante conhecido, mas que não se aplica na prática eclesial, segundo Comblin (2002).

O discurso da Teologia da Libertação ainda permeia a dimensão acadêmica do curso teológico, mas a prática eclesial da província, acompanhando a tendência neoconservadora mais geral (Benelli, 2006b), destoa dessa orientação teológica. O curso teológico atualmente insiste muito na doutrina e na moral ortodoxas. Mas, sem dúvida, os teólogos da libertação produziram textos de referência em diversas áreas da teologia, por isso ainda são estudados. Às vezes ouvimos alguns padres formadores e inclusive bispos se perguntando: "Por que os novos padres que estamos formando não são libertadores?” A intenção é que os padres sejam engajados e trabalhem pela transformação social. Eles escrevem isso em seus documentos, estatutos, regimentos. Mas, pensamos que instituições totalitárias e panópticas nas quais os atores não analisam suas próprias práticas não são capazes de preparar padres libertadores. É possível também que as atuais gerações de vocacionados não adiram ao ideário utópico libertador porque ele teria perdido sua pregnância por diversas razões. Aconteceram várias mudanças no plano sócio-cultural que influenciam fortemente os jovens da atualidade, inclusive os seminaristas teólogos (Libanio, 2005; Valle, 2003; Guerra, 2003, 2004).

A dimensão intelectual é a mais visível, melhor estruturada e mais passível de avaliação e de cobrança por parte de formadores e bispos, no processo formativo do seminário teológico. Chamou nossa atenção o fato de que não presenciamos os seminaristas teólogos discutindo os assuntos das aulas, seja no corredor, nos intervalos, ou nas muitas refeições que tomamos junto com eles. A impressão era de que os temas escolares não os empolgavam muito, nem estimulavam discussões e conversas, ficando reservados à sala de aulas ou aos estudos pessoais. Ora, conhecer e dominar os diversos aspectos dos saberes teológicos - bíblicos, espirituais, dogmáticos, morais e pastorais - parecenos um elemento importante na produção da subjetividade do futuro clero. Mas, nesse caso, talvez também valha o ditado “na prática, a teoria é outra”, expressando a distância que há entre uma preparação formal e intelectual e a vida concreta do sacerdote em pleno exercício do seu ministério.

O curso teológico, que está passando por uma fase de transformação em faculdade reconhecida, ainda estaria baseado numa concepção centrada na grade curricular de disciplinas e na transmissão de conteúdos padronizados. O currículo é pensado a partir de conteúdos considerados fundamentais que devem ser assimilados para sua posterior aplicação. A ênfase nos conteúdos é predominante, com pouco espaço para a preocupação com o desenvolvimento de competências e habilidades. A formação proposta ainda pode ser enquadrada no modelo fundamentação/ aplicação. Não se enfatiza a experiência de produção do conhecimento por meio da associação entre ensino, pesquisa e extensão, o foco está na apreensão de conteúdos prontos. Faltalhe um projeto de formação crítico que estivesse assentado numa perspectiva política e mística claramente definidas e implementadas na prática.

No seminário teológico encontramos o auto-exame e o consideramos como tecnologia pedagógica de formação. $\mathrm{O}$ exame, em suas diversas modalidades, foi considerado por Foucault (1999) como uma das importantes estratégias do poder disciplinar, em sua dimensão de objetivação, pois torna visível a conduta dos indivíduos por meio da vigilância e da observação. A confissão seria, por outro lado, uma técnica de subjetivação, pois quando um indivíduo elabora um discurso sobre si, ele se subjetiva, assumindo o enunciado como sendo parte constitutiva de sua identidade. Quando um indivíduo se auto-examina, seja de modo oral ou escrito, ele produz uma confissão sobre si e, ao mesmo tempo em que diz quem é e como se comporta, vai se definindo como sendo um tipo determinado de sujeito, no caso, um seminarista candidato ao sacerdócio. Normalmente os seminaristas teólogos elaboram um projeto de vida pessoal que deve ser entregue por escrito ao padre reitor. Esse documento é objeto de conversas nos encontros entre seminaristas e reitor. 
Também é comum que eles redijam uma auto-avaliação no final do ano sobre seu percurso formativo geral. Ela deve ser assinada e entregue ao padre reitor do seminário, que também a utilizará para a entrevista com o candidato. O esquema da proposta de auto-avaliação tematiza os aspectos globais do processo formativo: a questão vocacional, a dimensão espiritual, a comunitária, a humano-afetiva, a intelectual, a pastoral e finalmente solicita uma conclusão. $\mathrm{O}$ discurso do seminarista que aparece nesses documentos pode ser considerado típico, politicamente correto e formativamente adequado. Ele se inclui no discurso institucional oficial. De fato, não se poderia responder com fatos desabonadores, nem demasiado críticos. Trata-se de um documento redigido para agradar a autoridade. O que não quer dizer que ele seja necessariamente falso, mas não poderia ser muito diferente disso, sob pena de que o seminarista poderia ter "problemas" com os formadores do seminário teológico e com os de sua diocese. O mesmo se poderia dizer do projeto de vida pessoal dos teólogos. Soubemos que o reitor utiliza as informações que os seminaristas fornecem sobre si mesmos como base para preparar o relatório que envia aos bispos sobre o desempenho deles no processo formativo.

O padre diretor espiritual nos ofereceu seu projeto para a dimensão espiritual para o ano de 2005, que vamos comentar. O texto traz a lista das atividades espirituais cultivadas no seminário teológico, reflexões espirituais e propõem um programa prático que visa configurar o seminarista (futuro presbítero) a Jesus Cristo Sacerdote, Profeta e Pastor. Esse documento de circulação interna expressa o clima e a perspectiva espiritual predominante no seminário teológico, de acordo com nossas observações na instituição. Depois de esboçar o elenco geral das atividades da dimensão espiritual desenvolvidas no cotidiano e ao longo do ano no seminário teológico, é explicado, no projeto para a dimensão espiritual, o que entende por espiritualidade e, em seguida, é elaborada uma reflexão sobre a espiritualidade no processo de formação do futuro presbítero. Em seguida, apresenta-se propriamente um programa de espiritualidade, visando à configuração do seminarista a Jesus Cristo Sacerdote, Profeta e Pastor, buscando indicar atividades práticas em diversas dimensões. De acordo com a doutrina católica, o sacerdote, enquanto exerce suas funções ministeriais específicas, age in persona Christi, pois está configurado a Jesus Cristo pela ordenação sacerdotal. É difícil deixar de identificar que na base desse texto está o documento da Congregação para o Clero (2003) intitulado O presbítero: pastor e guia da comunidade paroquial. Esse documento apresenta um perfil sacerdotal bastante definido, que pode ser considerado tradicional. Certamente o modelo sacerdotal que está sendo proposto no programa desenvolvido pelo diretor espiritual pode enquadrar-se no denominado modelo cultual (Cozzens, 2001), muito mais do que no libertador.

A perspectiva espiritual que parece implícita no programa do diretor espiritual indicaria uma espiritualidade individual e verticalista, talvez mesmo individualista. Também nos pareceu espiritualizante e basicamente sacramental e cúltica. Não há indícios de ser uma espiritualidade encarnada na história, atenta aos problemas da vida social concreta; quando fala dos pobres, é no plano da caridade pastoral, não da justiça social, da transformação social. As orientações sobre os conselhos evangélicos de pobreza, castidade e obediência remetem a um padre que está mais para um monge do que para um sacerdote secular (Conferência Nacional dos Bispos do Brasil, 1995).

Notamos fortes traços monásticos e conventuais no programa: insistência na importância do silêncio, da oração pessoal, da meditação, de práticas devocionais e da oração da Liturgia das Horas. Podemos afirmar que o modelo monástico oferece a estrutura da espiritualidade proposta, apesar de o padre diocesano ser chamado a uma vocação eminentemente ativa. A oração parece a-histórica e intimista, o mesmo se pode dizer da Eucaristia, que não parece remeter a uma celebração da vida, mas apenas ao culto ritual. Há um destaque para a configuração do seminarista a Jesus Cristo Sacerdote, Profeta e Pastor que nos parece bastante clericalizante, ao identificar com exclusividade o seminarista com os poderes sacerdotais (culto e sacramentos), proféticos (anúncio, pregação da Palavra e ensino) e com o senhorio (pastoreio e governo) de Cristo. A vertente cristológica predomina claramente sobre a eclesiológica (Antoniazzi, 2003) no processo formativo.

Termos como compromisso, engajamento, transformação social, justiça social, opção pelos pobres estão ausentes do programa e talvez, também, da mentalidade dos jovens seminaristas e futuros presbíteros. Esse também foi o tom geral das diversas tardes de espiritualidade, momentos de adoração e celebrações diversas dos quais tivemos ocasião de participar. Pelo menos no plano do discurso, notamos que os motes da teologia da libertação desapareceram. É pouco provável que o tipo de orientação espiritual oferecido possa levar os seminaristas a serem futuros padres libertadores e engajados em trabalhos de transformação social. No instituto teológico investigado também observamos o que afirma Libanio (2005): “a consciência social e política dos religiosos declina (...) constata-se uma perda da garra no compromisso, um esfriamento do discurso libertador, uma retirada das comunidades inseridas com deslocamento da pastoral social para a litúrgico-sacramental.” (p. 71).

A prática litúrgica, que inclui celebrações da eucaristia diária, momentos de oração da Liturgia das Horas, de adoração ao Santíssimo Sacramento e outras práticas devocionais comunitárias, como a reza do terço, tem seus desafios, conforme pudemos observar: a rotina nas celebrações cotidianas; uma tendência rubricista, conservadora e ritualista; uma perspectiva intimista e subjetivista; o racionalismo próprio do período acadêmico da formação sacerdotal, que dificulta um enfoque espiritual, criando dificuldades de fé; a união da fé com a vida, ultrapassando a mera repetição ritual. A participação é obrigatória, mas pode acabar gerando uma adesão superficial que será abandonada assim que possível. Certamente, a vivência da liturgia seria um lugar privilegiado para o cultivo da espiritualidade e da mística cristã, mas notamos aí uma certa aridez.

\section{Discussão da observação participante no semi- nário teológico}

O seminário teológico é uma etapa avançada do processo formativo do candidato ao sacerdócio e nos parece dotado de especificidade própria, que estamos procurando mapear. $\mathrm{O}$ 
seminarista vive em comunidade e está diante da ordenação sacerdotal de modo muito concreto e próximo, desde o primeiro dia em que a começa a viver no seminário teológico. A decisão vocacional torna-se a questão fundamental. O candidato recebe formação teológica, doutrinal, espiritual e pastoral específicas para o futuro exercício do ministério presbiteral e vai percorrendo os diversos graus do sacramento da ordem: é admitido oficialmente como seminarista por sua diocese, recebe os ministérios de leitor e acólito; mais tarde é ordenado diácono, quando promete publicamente viver o celibato e, finalmente, o processo formativo culmina com a ordenação sacerdotal (Igreja Católica, 2004).

Temos observado que tornar-se membro da hierarquia eclesiástica católica exige como condição de possibilidade mudanças significativas na vida dos candidatos. As diversas dimensões do processo formativo visam operar formas de condutas específicas nos seus modos de ser, sentir e agir. Essas transformações são processadas na instituição de formação denominada seminário católico. O tempo aí vivenciado apresenta um caráter de iniciação prolongada, pleno de rituais religiosos e de operadores microfísicos, disciplinares e totalitários que incidem no corpo, na mente e na alma do seminarista, sobre a totalidade da vida de sua pessoa, produzindo um novo indivíduo consagrado e, normalmente, clericalizado. O enclaustramento e a interdição da vida sexual exigidas pela observação da regra do celibato são dois operadores importantes. Todo um conjunto de práticas e discursos implementados no âmbito do claustro institucional molda o corpo e a alma do candidato, sua personalidade, como suportes da consagração sacerdotal, buscando recriar sua identidade. Ele adquire novos hábitos, desenvolve uma visão diferente sobre si mesmo e sobre seu percurso existencial: seu corpo, seu psiquismo, sua história familiar, seus problemas cotidianos, afetivos, passam a ser interpretados e ressignificados pela sua vocação sacerdotal, num trabalho contínuo de construção da sua nova identidade. Assim se constitui gradualmente uma mentalidade de casta clerical. Podemos verificar como a produção de subjetividade se produz em meio a processos institucionais atravessados por práticas de saber, de poder e por tecnologias de si (Foucault, 1982, 1984, 1985, 1999).

De acordo com o que pudemos constatar na prática cotidiana, há notáveis diferenças entre o plano discursivo oficial e o plano não-discursivo. Uma das dimensões indicadas na literatura é a vida comunitária que, de acordo com nossas observações, tem como base uma certa privação da liberdade e a exclusão do trabalho remunerado. O regime de externato é substituído pelo do internato com todas as suas conseqüências. Podemos falar em uma tecnologia de enclaustramento totalitário (Goffman, 1987) que inclui como operadores a observação e vigilância hierárquica sobre o comportamento dos indivíduos, instituindo controle, sanção normalizadora e técnicas de exame (Foucault, 1999). O funcionamento automático dessa parafernália institucional parece produtor de medo e de um clima estressante, que pressiona anonimamente a todos, gerando, finalmente, resignação. A vida comunitária quase que se reduz aos momentos comuns, nos quais é obrigatória a presença coletiva: o horário da oração matinal e vespertina, das refeições, das celebrações da eucaristia, freqüência às aulas, assembléias, aos trabalhos domésticos e às reuniões por grupos diocesanos. Ser comunitário, basicamente, significaria estar formalmente reunido com o grupo no momento certo.

Embora os documentos e os discursos oficiais (João Paulo II, 1992; Conferência Nacional dos Bispos do Brasil, 1995, 2001) que circulam no seminário proclamem o protagonismo do formando, o que se verifica é de fato sua subordinação à autoridade e ao arbítrio dos padres formadores. A propalada formação participativa parece uma tentativa de incluir elementos democráticos numa estrutura demasiado vertical e autoritária. O pouco que se consegue é tratar de assuntos secundários em assembléias formais que também se prestam para que os padres formadores exerçam sua autoridade, buscando referendar suas decisões em votações com os seminaristas. Predomina mesmo uma formação tradicional e autoritária, com o poder político, econômico e deliberativo concentrado nos padres formadores e sobretudo na pessoa do padre reitor do seminário. No discurso, formadores e documentos pretendem buscar uma "formação personalizada”, mas suas práticas cotidianas, seus dispositivos e estruturas institucionais estão articulados de modo a fomentar uma formação uniforme e massificadora. Ao invés do trabalho profissional, temos a tutela econômica incompleta, propiciadora de um regime de "refenato" no qual os seminaristas se tornam dependentes das estruturas institucionais.

A dimensão da formação humano-afetiva pretende fundar-se em princípios humanistas e cristãos, pois um homem integral e integrado seria condição de possibilidade para a formação de um padre maduro e equilibrado. Trata-se de construir uma base humana sólida e saudável para poder educar o corpo e a sexualidade para o celibato: educar os sentimentos, cultivar relacionamentos sociais altruístas, manter uma convivência fraterna e harmoniosa em amizades sadias, realizar um trabalho solidário em equipe, ter responsabilidade no uso dos bens pessoais e coletivos, tornar-se capaz de integrar a genitalidade num projeto de vida casto. Aqui detectamos todo um processo de pedagogização e psicologização (inclusive de forte psicopatologização) dos comportamentos.

A Psicologia tradicional, centrada no indivíduo, psicologizante e patologizante da conduta e do comportamento pessoal parece prestar um grande desserviço para o processo formativo sacerdotal. Há uma terapeutização do cotidiano da vida do seminarista no seio de um seminário de formato monástico, que pretende realizar um trabalho de transformação do indivíduo em padre: tudo o que o seminarista faz pode ser tomado como índice de amadurecimento, imaturidade, enlouquecimento, vocação ou ausência dela, de acordo com a leitura dos padres formadores, colegas, professores e funcionários do estabelecimento. Nesse sentido, só o fato de viver no seminário realmente pode ser considerado como formativo em si mesmo, independente de atividades formativas específicas que venham a serem desenvolvidas.

A dimensão acadêmica do processo formativo deveria fornecer os elementos intelectuais e científicos que capacitassem o futuro presbítero para atuar como líder e dirigente da instituição paroquial. É a dimensão mais explícita do processo, a melhor organizada porque mais visível e normatizada, constantemente 
monitorada por outras instâncias (Ministério da Educação, Faculdade de Filosofia e Teologia). Haveria mesmo um processo de pedagogização e escolarização da formação sacerdotal. Quando não há aulas, curiosamente também não há seminário, pois o término do ano letivo coincide sempre com as férias dos seminaristas. Além disso, a conclusão das atividades acadêmicas praticamente indicaria que o seminarista cumpriu proveitosamente todos os requisitos para a ordenação sacerdotal e já pode recebê-la ou até mesmo exigi-la. A preparação acadêmica e profissional como bacharel em Filosofia e Teologia pode funcionar como cobertura ideológica para uma preparação de matiz fundamentalmente clerical, mesmo à revelia das intenções explícitas dos padres formadores e dos discursos plasmados na literatura pertinente. $\mathrm{O}$ ambiente acadêmico é centrado mais na dimensão doutrinal, dogmática e moral, do que na pesquisa e elaboração teológica.

Quanto à dimensão espiritual, a tendência que nos parece hegemônica atualmente é a de que o seminarista realize um percurso espiritual grupal, coletivo e institucional, centrado em práticas litúrgicas romanizadas, esmeradas e rubricistas, de tonalidade mais emocional, festiva, mágica, utilitarista e antiintelectual, negadora e alienada da realidade sócio-histórica. Embora haja a prática da oração pessoal entre os seminaristas, a busca de um caminho espiritual pessoal parece bastante incipiente. A formação espiritual é a mais exigente das dimensões da formação presbiteral. Ela é difícil de implementar, de se viver e de se avaliar porque não é fácil monitorar se o indivíduo está realmente trilhando um caminho de vida espiritual, de conversão.

Na direção espiritual, o padre responsável verifica através do relato do seminarista - que pode dizer o que quiser como vai sua vida espiritual. Parte-se do princípio de que o seminarista não tem porque mentir ou ocultar dificuldades e problemas pessoais ao padre diretor espiritual que está ali para auxiliá-lo. O seminário oferece retiros espirituais anuais, ritos, cerimônias, sacramentos diários, doutrina e estudos teológicos aos seminaristas, para alimentá-los espiritualmente. O impacto dos estudos filosóficos e teológicos tende a produzir efeitos racionalizadores e demolidores da experiência de fé ingênua e juvenil dos seminaristas. A vida nos conturbados bastidores do estabelecimento eclesiástico também produz danos na fé dos futuros presbíteros: não é difícil observar um apego formalista e vazio às práticas litúrgicas belamente encenadas em cerimônias pontificais, exuberantemente paramentadas, incensadas e estendidas ao máximo quanto à sua duração. Mas o rebuscamento dos enfeites e decorações não parece preencher o vazio de celebrações monótonas quase que desprovidas de motivação e de razões para serem executadas. Há muito cerimonial, mas talvez haja pouca mística e fé. O engajamento político e social, embora seja incentivado no plano discursivo (Conferência Nacional dos Bispos do Brasil, 1995, 2001), é substituído por um engajamento mais espiritualista, emocional e sobretudo ritual e cultual. A transformação histórica da sociedade parece ser substituída pela superação das contradições sociais no plano da transcendência religiosa.

A dimensão pastoral no processo formativo pode ser considerada como um treino para a futura prática pastoral clerical, provavelmente de matiz autoritária, concentradora e conservadora que o atual seminarista e futuro presbítero é chamado a experimentar. Conforme pudemos perceber, o pároco exerce o poder supremo no território paroquial, gozando de jurisdição universal, pois sua palavra equivale à lei: o que ele decide tem valor e deve ser executado. Provavelmente é isso que o seminarista tende a aprender na prática: “a arte das relações de poder” (Foucault, 1999, p. 245); o padre tem poder de mandar e as pessoas obedecem. Ele não precisa lançar mão de teorias científicas, de técnicas para planejamento e gerenciamento, nem para coordenar pessoas e grupos. Basta mandar. Seu poder deriva do mandato hierárquico conferido pelo bispo. Todos os conhecimentos filosóficos, teológicos, sociológicos, históricos, psicológicos, políticos sobrariam, seriam quase que um excesso e um luxo desnecessário. Aparentemente, quem tem poder não precisa saber nada, basta mandar. O seminarista, na pastoral, vive sob a influência, exemplo e jurisdição do pároco. Está exposto inclusive ao seu capricho e arbítrio. Onde não há lei, pode campear livremente o arbítrio. Nesse caso, o seminarista pode se dar muito bem ou muito mal, dependendo de sua sorte, da idiossincrasia do pároco de plantão e da sua capacidade diplomática ou de seu engenho na arte de manipular e de aproveitar as ocasiões favoráveis.

\section{Considerações finais}

A problematização genealógica tem seu ponto de partida na análise das relações de força e nas disposições táticas que perpassam as instituições. Visa estudar os procedimentos de constituição das instituições no nível das disposições de poder e dos processos de individualização e subjetivação que elas comportam. Todo microcosmo institucional está situado numa ampla rede social de estratégias de poder, saber e subjetivação, sua emergência é uma resposta a uma determinada problemática histórica. O que se busca saber é como determinada técnica de poder, alinhada com as forças sociais e as estruturas políticas constituem dispositivos que visam a uma gestão racional do indivíduo.

Dessa perspectiva, a análise do dispositivo seminário se articularia então em torno de três eixos: o do poder, no qual o padre formador se institui como sujeito agindo sobre os outros e sofrendo suas (re)ações; o eixo da verdade, na medida em que o seminarista é constituído em objeto de saber e conhecimento, na busca de sinais da vocação autêntica; e finalmente, o eixo da subjetivação, pois os atores institucionais devem adotar a identidade que lhes é prescrita.

O dispositivo seminário, no plano do poder, se organiza de modo disciplinar e totalitário, aplicando-se sobre os corpos dos atores institucionais: eles são repartidos no espaço institucional e seu comportamento observável, suas necessidades e prazeres são monitorados panopticamente. As relações de poder entre formadores e formando ainda se manifestam sob a forma instável de lutas e enfrentamentos permanentes, plenas de pontos de resistência.

O seminário também é um lugar no qual se produz um certo discurso de verdade, uma teologia da vocação sacerdotal. $\mathrm{Na}$ instituição de formação se articulam operadores do poder 
disciplinar com jogos de verdade: formulam-se uma teologia, uma pedagogia e uma psicologia do seminarista e do processo formativo, bem como uma técnica prática de formação. O padre formador, principalmente o reitor, se erige em mestre da realidade e da verdade e, por outro lado, enquanto o padre é o detentor do saber teológico, está também imbuído do poder sacerdotal e institucional que lhe foi conferido pela autoridade eclesiástica. Desse modo, a verdade surge como estratégia de legitimação do exercício do poder formativo clerical, dos seus discursos e práticas, autorizando sanções, exclusões e promoções.

Em tal cenário de assujeitamento, a subjetivação dos formandos se realiza sob a força de técnicas de exame (interrogatórios, formulários e questionários para serem respondidos, entrevistas mais ou menos periódicas, autoavaliação, auto-análise), procedimentos que, ao mesmo tempo em que buscam extrair um conteúdo da interioridade do indivíduo, promovem a interiorização das orientações, normas e modos de existência que lhe são impostos.

Verificamos que a formação do clero católico se produz em meio a relações sociais determinadas, estabelecidas sob bases paradigmáticas eclesiais específicas. Podemos considerar a vida presbiteral e o trabalho pastoral clerical como práticas institucionalizadas, socialmente legitimadas e legalmente sancionadas pela legislação eclesial. Entendemos que as condições estruturais e conjunturais da instituição eclesial impõem limites para a autonomia dos seminaristas e do clero em definir os rumos da sua ação eclesial, mas não os condicionam de modo absoluto e unidirecional. É possível evitar posicionamentos fatalistas que supõem a determinação material das opções eclesiais e também posturas messiânicas e voluntaristas ingênuas que desconhecem as coordenadas estruturais e conjunturais da realidade sócioeclesial. Para tanto, seria importante aproveitar as oportunidades e as brechas institucionais, buscando implementar mecanismos de participação coletiva, auto-análise e autogestão.

Notamos que a efetividade da formação sacerdotal parece consistir no desconhecimento da ação, das práticas institucionais cotidianas realizadas pelos diversos atores implicados na produção dessa realidade social específica. Foi a partir dessa hipótese que nos propusemos estudar a teoria da técnica da formação eclesiástica institucional. Caso isso se verifique, pensamos que uma das dificuldades para a compreensão e a elaboração dos problemas e do sofrimento psíquico institucionais que ali constatamos estaria nessa perspectiva individual e psicologizante, centrada predominantemente no seminarista. Uma análise dialética, focada no coletivo institucional, parecenos necessária e adequada para um equacionamento político, pedagógico (Costa-Rosa, 2000, 2006) e também místico (Lima Vaz, 2000; Pereira, 2004) dos problemas emergentes no seminário católico que estudamos.

\section{Referências}

Agência de Notícias Zenit. (2006). Seminário: qual o tripé de apoio - entrevista com D. Anuar Battisti. Revista Eclesiástica Brasileira, 66(264), 957-959.

Alves-Mazzotti, A. J., \& Gewndsznajder, F. (1998). O método nas ciências naturais e sociais: pesquisa quantitativa e qualitativa ( $2^{\underline{a}}$ ed.). São Paulo:
Pioneira.

Antoniazzi, A. (2003). Uma leitura teológico-pastoral. In E. Valle (Org.), Padre: você é feliz? Uma sondagem psicossocial sobre a realização pessoal dos presbíteros do Brasil (pp. 118-142). Brasília: CNBB/CNP/Loyola.

Baremblitt, G. F. (1998). Compêndio de análise institucional e outras correntes: teoria e prática. Rio de Janeiro: Record/Rosa dos Tempos.

Barus-Michel, J. (2004). O sujeito social. Belo Horizonte: Editora da PUCMinas.

Benelli, S. J. (2004). A instituição total como agência de produção de subjetividade na sociedade disciplinar. Estudos de Psicologia (Campinas), 21(3), 237252.

Benelli, S. J. (2006a). Pescadores de homens: estudo psicossocial de um seminário católico. São Paulo: Editora da UNESP.

Benelli, S. J. (2006b). Paradigmas eclesiais e pedagógicos na formação sacerdotal institucional: uma investigação em Psicologia Social. Revista Eclesiástica Brasileira, 66(264), 807-841.

Beozzo, J. O. (1993). A igreja do Brasil: de João XXIII a João Paulo II, de Medellín a Santo Domingo. Petrópolis: Vozes.

Boff, C. M. (1996). Uma análise de conjuntura da Igreja Católica no final do milênio. Revista Eclesiástica Brasileira, 56(221), 125-149.

Centini, A. (1997). Por amor: liberdade e maturidade afetiva no celibato consagrado. São Paulo: Paulinas.

Centini, A., \& Manenti, A. (1988). Psicologia e formação: estruturas e dinamismos. São Paulo: Paulinas.

Comblin, J. (2002). O povo de Deus (2ª ed.). São Paulo: Paulus.

Conferência Nacional dos Bispos do Brasil. (1995). Formação dos presbíteros da igreja no Brasil: diretrizes básicas. São Paulo: Paulinas.

Conferência Nacional dos Bispos do Brasil. (2001). Metodologia do processo formativo: a formação presbiteral na igreja do Brasil. São Paulo: Paulus.

Congregação para o Clero. (2003). O presbítero: pastor e guia da comunidade paroquial. São Paulo: Paulinas.

Costa-Rosa, A. (2000). O modo psicossocial: um paradigma das práticas substitutivas ao modo asilar. In P. D. C. Amarante (Org.), Ensaios de loucura e civilização (pp. 141-168). Rio de Janeiro: Fiocruz.

Costa-Rosa, A. (2006). A instituição de saúde mental como dispositivo social de produção de subjetividade, Manuscrito não-publicado, Universidade Estadual Paulista, Assis, SP.

Cotrim, G. (1993). Educação para uma escola democrática. História e Filosofia da Educação. (5⿳亠丷a ed.). São Paulo: Saraiva.

Cozzens, D. B. (2001). A face mutante do sacerdócio. Reflexão sobre a crise da alma do sacerdote. São Paulo: Loyola.

Ferreira Neto, J. L. (2004). A formação do psicólogo. Clínica, social e mercado. São Paulo: Escuta.

Foucault, M. (1982). A vontade de saber. Rio de Janeiro: Graal.

Foucault, M. (1984). A verdade e as formas jurídicas. Rio de Janeiro: Editora da PUC-RJ.

Foucault, M. (1985). O cuidado de si. Rio de Janeiro: Graal.

Foucault, M. (1999). Vigiar e punir: nascimento da prisão. Petrópolis: Vozes.

Goffman, E. (1987). Manicômios, prisões e conventos. São Paulo: Perspectiva.

Guerra, L. D. (2003). Mercado religioso no Brasil: competição, demanda e a dinâmica da esfera da religião. João Pessoa: Idéia.

Guerra, L. D. (2004). As influências da lógica mercadológica sobre as recentes transformações na Igreja Católica. Razão e Fé, 6(1-2), 105-128.

Igreja Católica. (1982). Compêndio do Vaticano II. Petrópolis: Vozes.

Igreja Católica. (1983). Código de direito canônico. São Paulo: Loyola.

Igreja Católica. (1985). Ratio fundamentalis institutionis sacerdotalis. Madri: Loyola.

Igreja Católica. (2004). Pontifical romano. São Paulo: Paulus.

João Paulo II (1992). Sobre a formação dos sacerdotes. São Paulo: Paulinas.

Libaneo, J. C. (1994). Tendências pedagógicas na prática escolar. In C. C. Luckesi (Org.), Filosofia da Educação (pp. 53-74). São Paulo: Cortez.

Libanio, J. B. (1984). A volta à grande disciplina. São Paulo: Loyola. 
Libanio, J. B. (2000). Cenários da igreja. São Paulo: Loyola.

Libanio, J. B. (2005). Impactos da realidade sociocultural e religiosa sobre a vida consagrada a partir da América Latina. Busca de respostas. Perspectiva Teológica, 37, 55-88.

Lima Vaz, H. C. (2000). Experiência mística e filosofia na tradição ocidental. São Paulo: Loyola.

Losada, M., Lapenta, V. H. S., Sá, O., \& Almeida, D. B. (1999). A vida religiosa enquanto instituição: leitura psicológica. Rio de Janeiro: CRB/Loyola.

Lourau, R. (1996). A análise institucional. Petrópolis: Vozes.

Maciel, M. (1992). A formação integral do sacerdote católico. São Paulo: Loyola.

Marmilicz, A. (2003). O ambiente educativo nos seminários maiores do Brasil: teoria e prática. Curitiba: Vicentina.

Mézerville, G. (2000). Maturidade sacerdotal e religiosa: um enfoque integrado entre psicologia e magistério (J. R. Costa, Trad.). São Paulo: Paulus.
Moro, C. (1997). A formação presbiteral em comunhão para a comunhão: perspectivas para as casas de formação sacerdotal. Aparecida, São Paulo: Santuário.

Nouwen, H. J. M. (2001). Intimidade: ensaios de psicologia pastoral. São Paulo: Loyola.

Organização dos Seminários e Institutos Teológicos do Brasil. (2004). A formação presbiteral: memórias e perspectivas. Brasília: Autor.

Pereira, W. C. C. (2004). A formação religiosa em questão. Petrópolis: Vozes.

Pereira, W. C. C. (Org.). (2005). Análise institucional na vida religiosa consagrada. Belo Horizonte: CRB.

Richardson, R. J. (1985). Pesquisa social: métodos e técnicas. São Paulo: Atlas.

Valle, E. (Org.). (2003). Padre: você é feliz? Uma sondagem psicossocial sobre a realização pessoal dos presbíteros do Brasil. Brasília: CNBB/CNP/ Loyola.

1. Este artigo é parte da tese de doutorado: “A produção da subjetividade na formação contemporânea do clero católico”, desenvolvida pelo autor, sob orientação de Geraldo José de Paiva, na Pós Graduação em Psicologia Social, Instituto de Psicologia, Universidade de São Paulo, e que contou com financiamento da CAPES.

2. O candidato à ordem sacerdotal, o seminarista, tem um longo percurso de formação teórica e prática, humana e espiritual, que se realiza nos chamados seminários diocesanos. Ele deve concluir os estudos do ensino médio e depois cursar três ou quatro anos de Filosofia e quatro anos de Teologia nos chamados seminários maiores. Esse processo pode durar mais ou menos tempo, dependendo da etapa escolar na qual o candidato se encontra quando ingressa no processo formativo. Mas, concluído o ensino médio, ele ainda tem pelo menos mais sete anos de formação. Também existem os seminários menores, onde os candidatos podem permanecer enquanto concluem o ensino médio. Assim, um candidato à ordem sacerdotal precisa de mais ou menos oito anos para se formar e ser ordenado, podendo percorrer pelos menos três tipos de seminários: o menor, também chamado de propedêutico, o maior de Filosofia e o maior de Teologia.

Silvio José Benelli, doutor em Psicologia Social pelo Instituto de Psicologia da Universidade de São Paulo, é pesquisador de pós-doutorado junto ao Departamento de Psicologia Clínica da Faculdade de Ciências e Letras da Universidade Estadual Paulista (UNESP), Campus Assis, SP. Endereço para correspondência: R. José Bonifácio, 1185, Apto. 41-B (Jardim Cristo Rei); Marília, SP. Telefones/fax: (14) 3422-5040; Cel. (14) 9796-2311. E-mail: sjbewelli@yahoo.com.br 